\title{
Corrosion analysis of graphite sinter as bipolar plates in the low-temperature PEM fuel cell simulated environments
}

\author{
Renata Włodarczyk ${ }^{1}$ (D)
}

Received: 2 March 2021 / Revised: 18 June 2021 / Accepted: 24 July 2021 / Published online: 2 August 2021

(c) The Author(s) 2021

\begin{abstract}
The article presents the results of research and an analysis of the possibility of using sinters made of graphite powder as a material dedicated to the production of bipolar plates for low-temperature fuel cell. The use of powder metallurgy technology allows for the production of materials that meet the requirements for fuel cell elements for the construction of elements closing a single cell (bipolar or monopolar plates) or interconnectors. The morphological and chemical analysis of graphite powder, microstructural analysis of the produced graphite sinter, and the analysis of functional properties, i.e., porosity, roughness, and corrosion resistance under operating conditions of a low-temperature fuel cell, were performed. The corrosion resistance of the graphite sinter was tested in anodic conditions (in a corrosive environment saturated with hydrogen) and in cathodic conditions (in a corrosive environment saturated with oxygen). Graphite sinters show high resistivity in both tested corrosive environments, which allows the use of powder metallurgy technology for serial production of covers for low-temperature fuel cells.
\end{abstract}

Keywords Graphite $\cdot$ Bipolar plates $\cdot$ Corrosion analysis $\cdot$ Wettability $\cdot$ Potentiostatic curve $\cdot$ PEMFC

\section{Introduction}

By following the development of fuel cell technology, you can observe a variety of applications for this type of energy generator. In the power industry, the use of fuel cells in lowand medium-power units is considered also as dispersed sources of heat and electricity. Fuel cells can be used as home power generators, voltage support systems, and emergency power generators in hospitals; they can power traffic lights and constitute independent power plants [1]. High costs of materials for the construction of individual elements of the single cell, expensive catalysts, and fuel storage methods are the main barrier to the wider commercialization of these solutions. At present, therefore, intensive work is being done on solving the issue of obtaining and storing hydrogen, increasing the lifetime of the cell, reducing the production

Dedicated to Prof. Marassi—scientist, mentor, friend.

Renata Włodarczyk

renata.wlodarczyk@pcz.pl

1 Department of Advanced Energy Technologies, Faculty of Infrastructure and Environment, Czestochowa University of Technology, Częstochowa, Poland costs of generators, and miniaturization of the generator itself and auxiliary devices.

A fuel cell is an electrochemical device in which the chemical energy contained in the fuel is directly converted into electricity. Only water and heat are by-products of this conversion [2]. The intensity of the electrochemical processes taking place, the properties of the materials used for the elements of the cell, and the working environment of the cell are factors that significantly affect the amount of electricity produced [3]. The decisive influence on the reduction of the generator mass and the increase of the cell's service life lies on the side of the bipolar plates/interconnectors. As it results from [4] in the case of a generator weighing $24 \mathrm{~kg}$ and a power of $33 \mathrm{~kW}, 81 \%$ of the mass are interconnectors; the rest of the mass are closing plates, seals, and a membrane with electrodes. When analyzing the expenditure per cell, interconnectors also play an important role, as they account for $45 \%$ of the generator's costs. The answer to the problems that stand in the way of commercialization is the use of available and cheap material, at the same time with high resistivity to the conditions inside the cell.

For commercial purposes, bipolar plates in fuel cell are made of non-porous graphite due to its high corrosion resistance [5]. However, the disadvantage of this material is that 
non-porous graphite covers cannot be made as thin elements and processing of this type of material is difficult [6]. Taking into account the functions of the bipolar plates in the fuel cell, and taking into account the production costs and the required weight of this type of generators, the covers must be made of cheap, light, and easy-to-machine material. Metal materials for fuel cell covers include uncoated stainless steels, aluminum, titanium, nickel, and materials with conductive coatings and nitrogen and carbon coatings [7-9]. It is also possible to use metal-based composites.

The article presents the results of research and an analysis of the possibility of using sinters made of graphite powder as a material dedicated to the production of bipolar plates for low-temperature fuel cell. The use of powder metallurgy technology allows for the production of materials that meet the requirements for fuel cell elements for the construction of elements closing a single cell or interconnectors. As part of the work, the morphological and chemical analysis of graphite powder, microstructural analysis of the produced graphite sinter, and the analysis of functional properties, i.e., porosity, roughness, and corrosion resistance under operating conditions of a low-temperature fuel cell, were performed. The corrosion resistance of the graphite sinter was tested in anodic conditions (in a corrosive environment saturated with hydrogen) and in cathodic conditions (in a corrosive environment saturated with oxygen). As results from the conducted analyzes, sintered graphite shows high resistivity in both tested corrosive environments, which allows the use of powder metallurgy technology for serial production of bipolar plates for lowtemperature fuel cells.

\section{Experimental}

\section{Methods}

Microstructure analysis has been done using the scanning electron microscope (SEM) Philips XL30/LaB6.

Sieve analysis was examined to determine the size of the graphite powder particles (PN-EN 24,497, ISO 4497). Sieve analysis is one of the most important analyzes carried out for powder materials. This analysis makes it possible to examine the share of particular grain sizes in the tested powder. For this purpose, sieves with different mesh sizes (here from $150 \mu \mathrm{m}$ to $45 \mu \mathrm{m}$ ) are used. The sieve with the largest mesh size of $150 \mu \mathrm{m}$ is placed on top, in the sieve with the finest mesh of up to $45 \mu \mathrm{m}$. A powder sample of known weight is placed on the upper sieve, and the entire set of sieves is placed on a shaker that generates vibrations. After completing the test, the mass of powder remaining on the individual sieves and the mass of powder passing through the sieve with the smallest mesh were weighed. Knowing the mass of the powder remaining on the sieves, the percentage content of individual fractions can be determined.

In order to determined phase and chemical analysis of graphite powder, the analysis with spectrometer XRD (X-ray diffraction) (Seifert 3003 T-T)-cobalt lamp with the wavelength of the characteristic radiation $\lambda \mathrm{C}_{0} \mathrm{~K}_{\alpha}=0.17902 \mathrm{~nm}$ has been done.

Using the method of mercury porosimetry determined open porosity, bulk density, and specific surface area of sintered graphite. The mercury porosimeter PoreMaster33 with software Quantachrome Instruments for Window was used. Apparent density takes into account the presence of the connecting channels' open pores of the porous material.

In order to determine the surface topography and surface geometry parameters, studies were carried out using the profilometer Hommel T1000 software QuickReport Reader1.2. Tests were performed in triplicate for sample; the values were averaged.

In order to determine the type of materials produced under the terms of wettability, $3 \mu 1$ water on the surface of the previously polished and defatted materials was applied. Wettability test was performed 3-5 times for each sample and the results averaged. The contact angle was determined using the microcamera MicroCapture.

Potentiokinetic and potentiostatic tests were carried out in a three-electrode system: the working electrode was the material being tested, the reference electrode was a saturated calomel electrode (SCE), and the auxiliary electrode was a platinum wire [10].

Potentiokinetic test carried out in $0.1 \mathrm{~mol} \mathrm{dm}^{-3}$ $\mathrm{Na}_{2} \mathrm{SO}_{4}+2 \mathrm{ppm} \mathrm{F}^{-}, \mathrm{pH} 1.00, \mathrm{pH} 3.00, \mathrm{pH} 5.00$ solution at temperature $T=80{ }^{\circ} \mathrm{C} \pm 2{ }^{\circ} \mathrm{C}$, with scan potential rate $5 \mathrm{mV} \mathrm{s}^{-1}$. Potential range changed from $-0.8 \mathrm{~V}$ vs. SCE to $1.8 \mathrm{~V}$ vs. SCE potential. Potentiostatic test carried out in $0.1 \mathrm{~mol} \mathrm{dm}^{-3} \mathrm{H}_{2} \mathrm{SO}_{4}+2 \mathrm{ppm} \mathrm{F}^{-}, T=80{ }^{\circ} \mathrm{C} \pm 2{ }^{\circ} \mathrm{C}$, saturated with hydrogen and oxygen produced in electrolyzer. Polarization curves were recorded by means of electrochemical measuring station CHI 1140 (CH Instruments, USA) connected to a computer. Based on the polarization curves, the following corrosion parameters were determined or estimated: corrosion potential $\left(E_{\text {corr }}\right)$ [V], current density $\left(i_{\text {corr }}\right)\left[\mathrm{A} \mathrm{cm}^{-2}\right]$, current density at anode potential $E=-0.1 \mathrm{~V}$ vs. SCE at cathode potential $E=0.6 \mathrm{~V}$ vs. SCE $\left[\mathrm{A} \mathrm{cm}{ }^{-2}\right]$, polarization resistance $\left(R_{\mathrm{p}}\right)$ $\left[\Omega \mathrm{cm}^{2}\right]$. The corrosion current density was determined by extrapolating the tangent to the anodic potentiokinetic curves with a slope of $0.04 \mathrm{~V} /$ decade (it was assumed that the anodic dissolution process of the tested material follows the Bockris mechanism [11]). The polarization resistance was determined on the basis of the recorded 
Table 1 Technological parameters of graphite powder

\begin{tabular}{llll}
\hline Powder & $\begin{array}{l}\text { Powder denisty } \\
{\left[\mathrm{g} \mathrm{cm}^{-3}\right]}\end{array}$ & $\begin{array}{l}\text { Bulk density powder } \\
{\left[\mathrm{g} \mathrm{cm}^{-3}\right]}\end{array}$ & $\begin{array}{l}\text { Flowability } \\
{[\mathrm{s} / 50 \mathrm{~g}]}\end{array}$ \\
\hline Graphite & 2.2 & 0.2 & 13.0 \\
\hline
\end{tabular}

potentiokinetic curves. The dependence was used that in the range of $E_{\text {corr }} \pm 20 \mathrm{mV}$, the external current density is a linear function of the potential, and the tangent of the slope of the relationship $E=\mathrm{f}(i)$ is inversely proportional to the corrosion rate.

The evaluation of the value of errors in the measurements of corrosion resistance consisted in a fivefold repetition of the recorded potentiokinetic curves. After comparing the course of the curves, a representative curve lying between the repeated curves was selected for parameter analysis. The mean values of the corrosion parameters are presented in Table 4 and Table 5. For the analysis of measurement errors, standard deviations $\sigma$ were determined for each parameter.

\section{Materials}

\section{Properties of powder graphite}

The commercial graphite powder Graphite FC firmy Schunk Kohlenstofftechnik GmbH (Germany) was used to prepare the graphite sinter (Table 1).

Figure 1 shows the morphology of graphite powder. The shape of the particles indicates the method of obtaining graphite powder. Plate-shaped particles were obtained by the Hametag method by mechanical grinding using fastrotating propellers.

Based on the sieve analysis, the share of individual fractions in a given grain class was estimated (Table 2). The values in Table 2 with a "+" sign indicate the percentage
Table 2 Particles size distribution of graphite powder
Particles Share of fractions in size $[\mu \mathrm{m}]$ the grain class [\%]

\begin{tabular}{lr}
\hline+150 & 0.12 \\
+125 & 1.23 \\
+106 & 3.11 \\
+75 & 3.20 \\
+53 & 8.44 \\
+45 & 42.15 \\
-45 & 41.75
\end{tabular}

of the given graphite powder fraction remaining on the sieve with the appropriate mesh size, while the value with the "-" sign representing the proportion of the powder fraction that passed through the finest mesh sieve, here $45 \mu \mathrm{m}$. This means that $41.75 \%$ of the powder has a particle size below $45 \mu \mathrm{m}$.

Figure 2 shows the diffractograms registered for graphite powder. Based on X-ray analysis, a type of graphite with a hexagonal cell was revealed with the following parameters: $a=b=0.245 \mathrm{~nm}, c=0.669 \mathrm{~nm}, \alpha=\beta=90^{\circ}$, $\gamma=120^{\circ}$ (synthetic graphite) [12].

\section{Preparation of graphite sinters}

Sintered graphite was obtained using powder metallurgy technology. The powders were poured loosely into a steel die and pressed under a pressure of $700 \mathrm{MPa}$. The powder was pressed without the use of lubricants, pressing speed: $0.5 \mathrm{~min} / \mathrm{MPa}$, pressing time/pressure duration: $1 \mathrm{~min}$, uniaxial pressing. The compacts were tablet-shaped. The next step was the sintering process. The moldings were pressed in a die of $0.002-0.003 \mathrm{MPa}$, after heating the die to $800 \mathrm{~K}$, the pressure was $0.015 \mathrm{MPa}$. The average heating rate was $270 \mathrm{~K} / \mathrm{min}$. After reaching $1373 \mathrm{~K} \pm 40 \mathrm{~K}$, the compacts were sintered for $30 \mathrm{~min}$.

Fig. 1 Graphite powder morphology
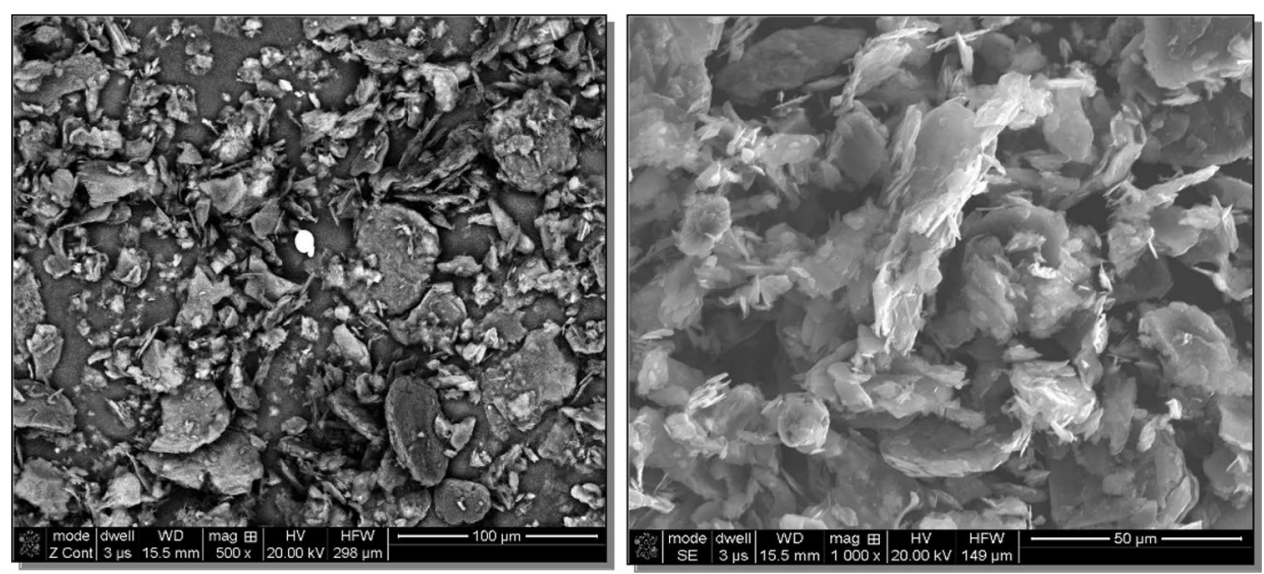


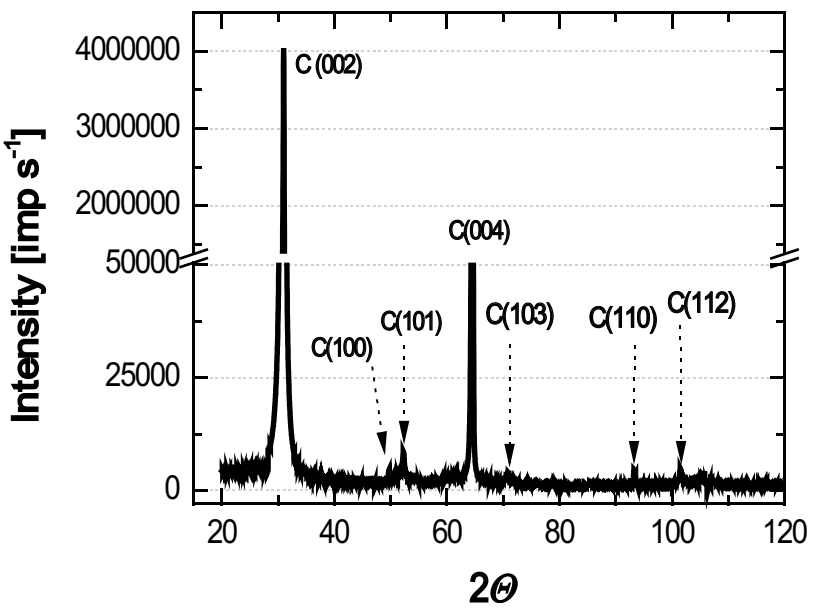

Fig. 2 Graphite powder diffractogram

\section{Results and discussion}

\section{Microstructure analysis}

Figure 3 shows that the microstructures of graphite materials obtained as a result of pressing with subsequent sintering of graphite powder are presented. The image of the sinter microstructure indicates that the sintering resulted in a porous material; the figure shows open pores, the size and volume of which were estimated on the basis of porosimetric analysis.

\section{Analysis of porosity}

According to the IUPAC classification [37], this range includes mesopores $(2<d<50 \mathrm{~nm})$ and macropores $(d>50 \mathrm{~nm})$ and micropores $(d<2 \mathrm{~nm})$. Micropores and mesopores determine the size of the internal surface, while macropores have a small share in the total internal surface and play the role of transport routes, allowing access to pores of smaller sizes. However, taking into

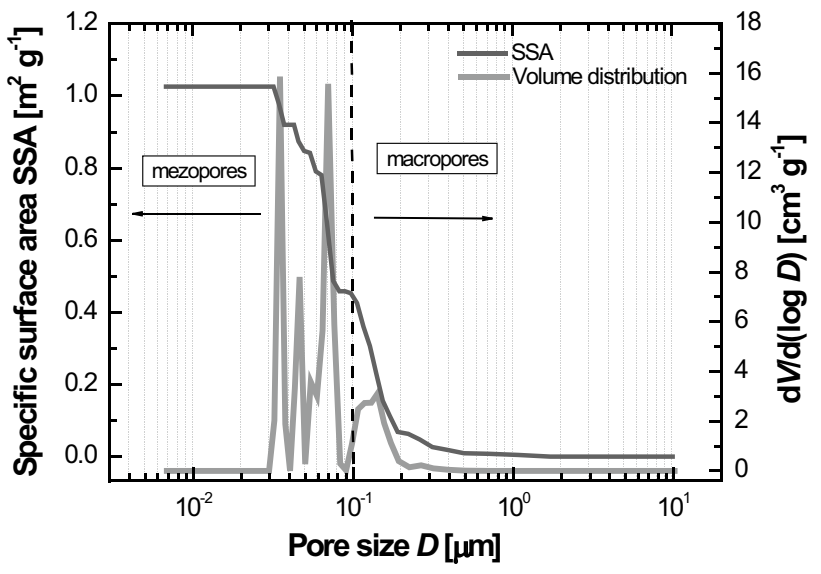

Fig. 4 Specific surface area and pore volume distribution as a function of their diameters determined for graphite sinter

account that the pores of the tested sinter will be flow channels during the operation of the cell, it is the number of macro- and mesopores that should determine the size of the surface directly involved in electrochemical reactions. Figure 4 shows the pore volume distribution of sintered graphite as a function of their size (diameter) and the influence of individual pore sizes on the value of the specific surface area (SSA) of the sinter. As can be seen, the SSA value is predominantly influenced by pores in the meso range.

The mercury porosimeter registers the volume of mercury penetrating into the pores of the tested material and enables the development of a pore volume distribution curve depending on their size. The pore radii corresponding to the specified pressure values are automatically calculated by the PoreMaster program. Thus, the obtained results can be presented in the form of a $d V / d(\log D)$ relationship, where $v$ is the volume of mercury injected into the pores of grains with a specific diameter $D$. Due to the large dispersion of pressure and pore diameter, the results are presented in a logarithmic system.
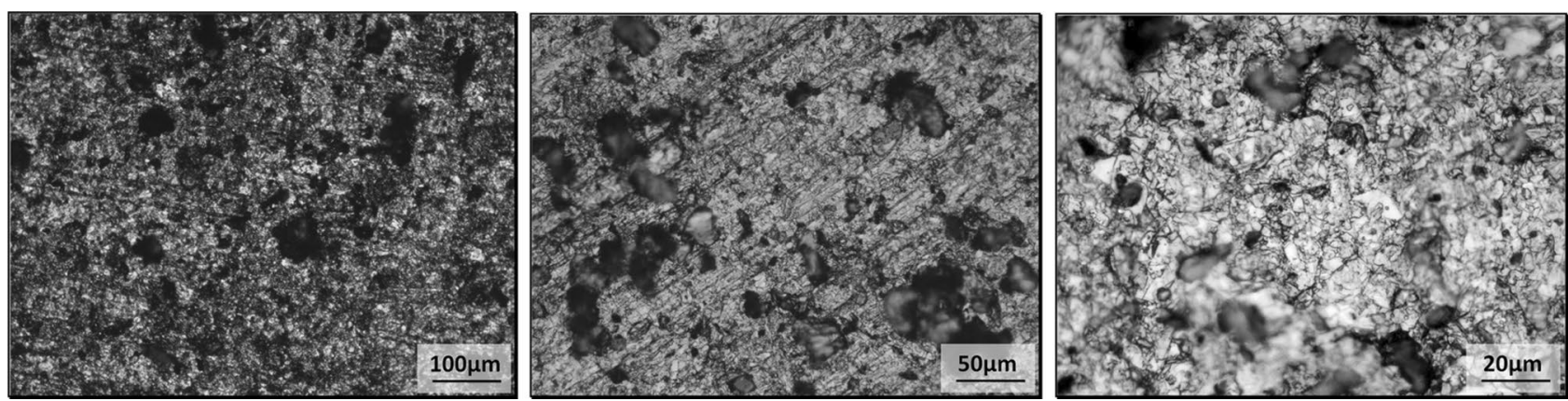

Fig. 3 The microstructure of the graphite sinter 


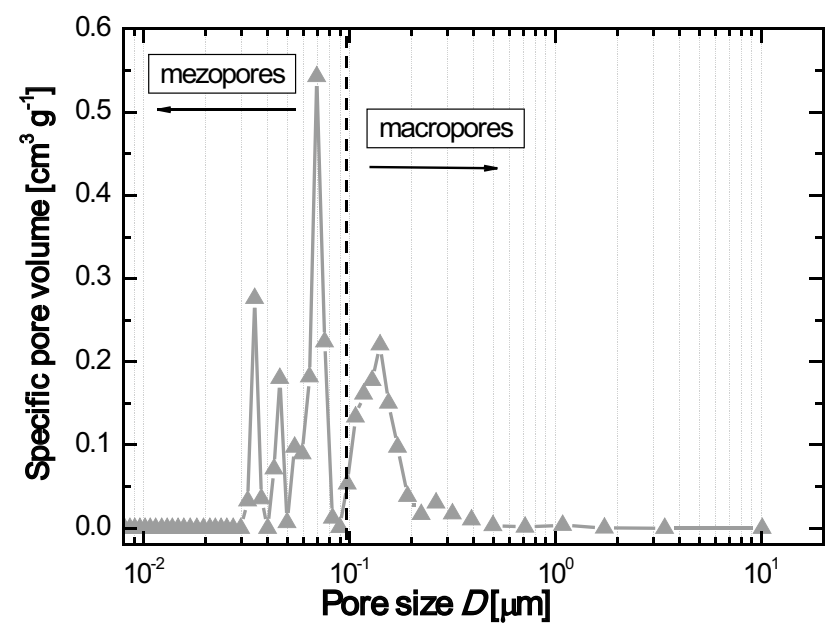

Fig. 5 Unit pore volume as a function of pore diameter determined for the graphite sinter

Figure 5 shows the unit pore volume relative to the mean pore diameter. The pore distribution in terms of radii is not uniform (it does not resemble a symmetrical bell curveGaussian distribution). The distributions also do not show bimodal distributions with two maxima. The pore distribution on the surface of the particles of the examined graphite materials is more complex (heterogeneous) with various pore sizes. In the case of heterogeneous pore volume distribution, it is more difficult to interpret the curves to describe the actual pore structure inside the particles. Most of the wider pores may be present, for example, on the surface of the powder particles, or between them, while the narrower pores may be inside the particles, being an extension of the wider pores. Pores in the meso- and macropore ranges can be observed in the studied material.

\section{Roughness analysis}

The geometrical parameters of the surface of the materials intended for fuel cell bipolar plates have an influence on the effect related to the surface contact resistance. Uneven, rough surfaces show a low proportion of the contact area between the cover and the electrode diffusion layer and thus a high interfacial resistance between the interconnector surface and
Table 3 Parameters of sintered graphite

\begin{tabular}{ll}
\hline Parameters & Sintered graphite \\
\hline Density $\left[\mathrm{g} \mathrm{cm}^{-3}\right]$ & 2.25 \\
Porosity $[\%]$ & 5.36 \\
Specific surface area $\left[\mathrm{m}^{2} \mathrm{~g}^{-1}\right]$ & 1.18 \\
$R_{\mathrm{a}}[\mu \mathrm{m}]$ & 2.088 \\
$R_{\mathrm{z}}[\mu \mathrm{m}]$ & 8.501 \\
Contact angle $[\mathrm{deg}]$ & 122 \\
\hline
\end{tabular}

the electrode diffusion layer. The effect of this is the loss in the cell due to the high interfacial resistance at a given pressure. In order to eliminate the negative effect, the covers made of graphite are additionally polished to increase the contact area $[13,14]$. The parameters of the surface geometry of the material are also important for corrosion resistance. Based on the analysis of the surface of the shells, the values of the parameters describing the height features of the profile were determine $[15,16]: a$-arithmetic mean deviation of the roughness profile from the mean line, $R_{\mathrm{z}}$-maximum profile height (see Table 3). Figure 6 shows the roughness profile recorded for the tested sintered graphite sample. $R_{\mathrm{a}}$ decomposes between +5.0 and $-7.5 \mu \mathrm{m}$ from the meanline profile. Figure 7

\section{Wettability}

In a low-temperature PEMFC fuel cell, electrochemical processes take place in an aquatic environment. Appropriate humidification of the introduced gases prevents the membrane from drying out and losing its ion-exchange properties. In addition, water is produced at the positive electrode of the cell (cathode) by reducing oxygen. One of the main tasks of the covers is to evenly distribute gases over the surface of the electrodes and to drain water from the cell. Bipolar plates for fuel cell are in constant contact with water and moist gases. If liquid water accumulates in the cell, it will block the gas reaction at the electrodes. In addition to the appropriate shaping of the channels on the surface of the covers, it would therefore be advisable that the materials from which these covers are made are non-wettable [17-20]. This is important both for the operation of the cell and for
Fig. 6 Roughness profile recorded for graphite sinter

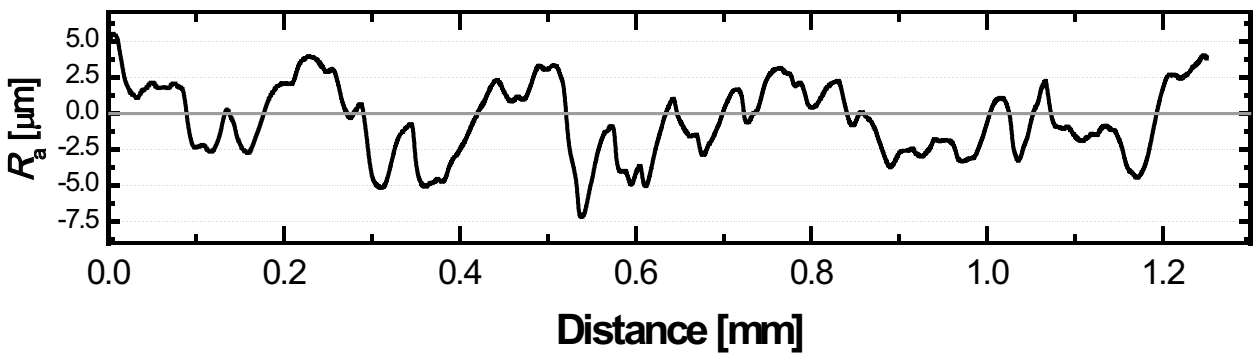




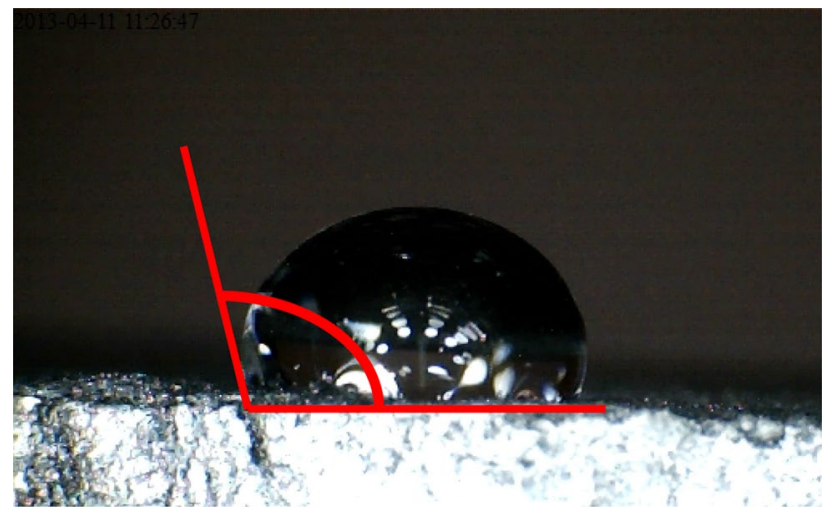

Fig. 7 The contact angle is determined for the sintered graphite

corrosion of the components in the cell. Water remaining on the surface of the metal leads to the initiation of corrosive processes [21]. Therefore, the use of hydrophobic materials supports the operation of the cell and affects its cost; thanks to the implementation of hydrophobic materials, the auxiliary humidification system of the media introduced into the cell can be simple and uncomplicated. Figure 7 shows the method of distribution of the droplets on the sintered graphite and the value of the angle $\Theta$ (Table 3).

\section{Corrosion analysis}

In Fig. 8 and Fig. 9, the potentiokinetic curves recorded for sintered graphite are shown. Graphite materials under the operating conditions of a fuel cell do not undergo passivation [22]. Among other things, the lack of the passivation phenomenon makes graphite attractive for elements of low-temperature fuel cells. The corrosive process of carbon materials in the acidic environment of a cell with a proton exchange membrane proceeds according to the following reaction:

$\mathrm{C}+2 \mathrm{H}_{2} \mathrm{O} \rightarrow \mathrm{CO}_{2}+4 \mathrm{H}^{+}+4 \mathrm{e}^{-}$

This reaction is thermodynamically possible for the potentials at which the cell's cathode operates (with values of approx. $0.6 \mathrm{~V}$ vs. SCE). Although the rate of this reaction is negligibly slow, especially at low operating temperatures of the PEMFC cell, it can affect the cell's lifetime. In the works, the problem of corrosion of carbon materials acting as catalyst supports on electrodes is widely described and analyzed [23, 24]. Corrosion of the support insulates the surface of the catalyst, which inhibits electrode processes in the cell. As a result of the conducted research, it was observed that transitional processes in which the intermediate product was $\mathrm{CO}$, the reduction of the specific surface of the catalyst caused by gas absorption was indicated, difficulties in diffusion of gases through the diffusion layer (made of carbon materials) of the electrodes were observed $[25,26]$. The above problems are eliminated by the use of platinum alloys with metals of transition groups in order to bind the carbon monoxide $\mathrm{CO}$ deposited on the platinum surface [27-30].

No less important as the corrosion of carbon catalyst carriers is the corrosion of elements adjacent to the diffusion layers, i.e., bipolar or monopolar plates. Due to the variable operating environment of the cell, the corrosion resistance of graphite materials was analyzed depending on the $\mathrm{pH}$ of the solution. Corrosive solution was saturated with oxygen (cathode conditions-Fig. 8) or hydrogen (anode conditions-Fig. 9). As can be seen from the course of the

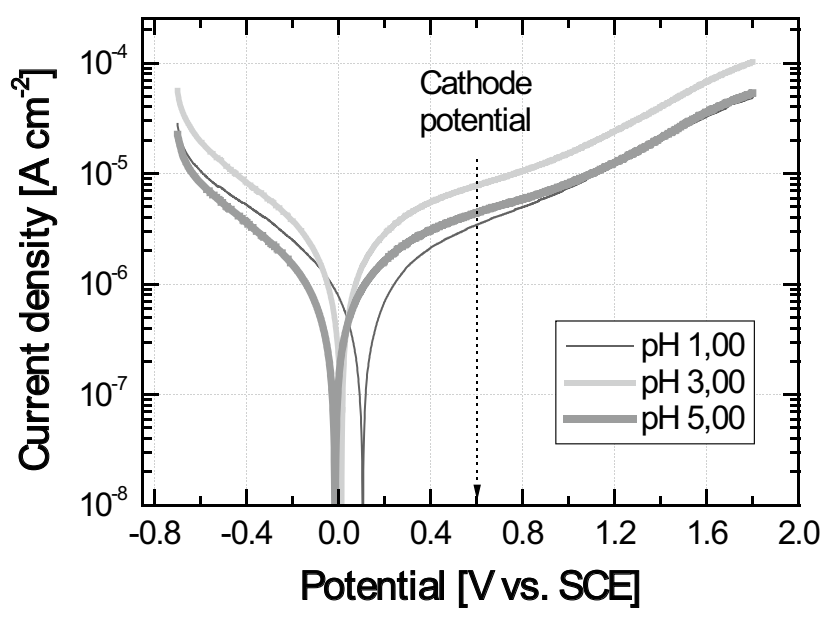

A)

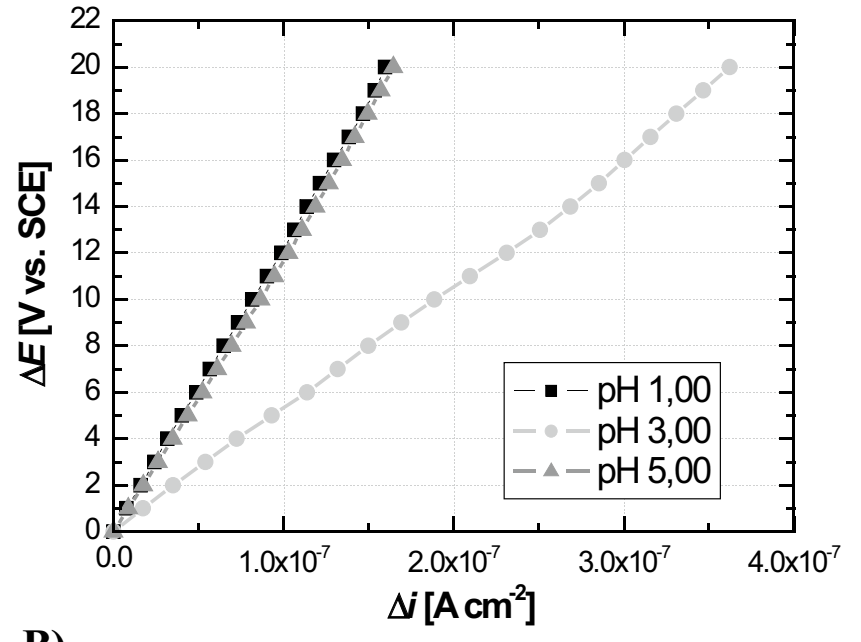

B)

Fig. 8 A Potentiokinetic curves recorded in a solution with a variable $\mathrm{pH}$ saturated with oxygen. B Change in the value of external current as a function of the applied voltage (in the range of $E_{\text {corr }}+\Delta E$ ) of the analyzed material on the basis of the recorded potentiokinetic curves 


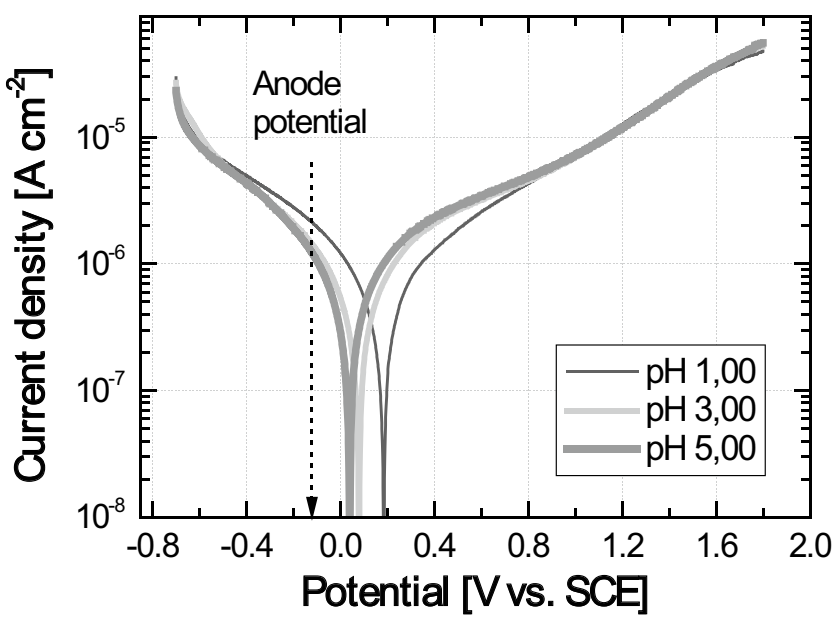

A)

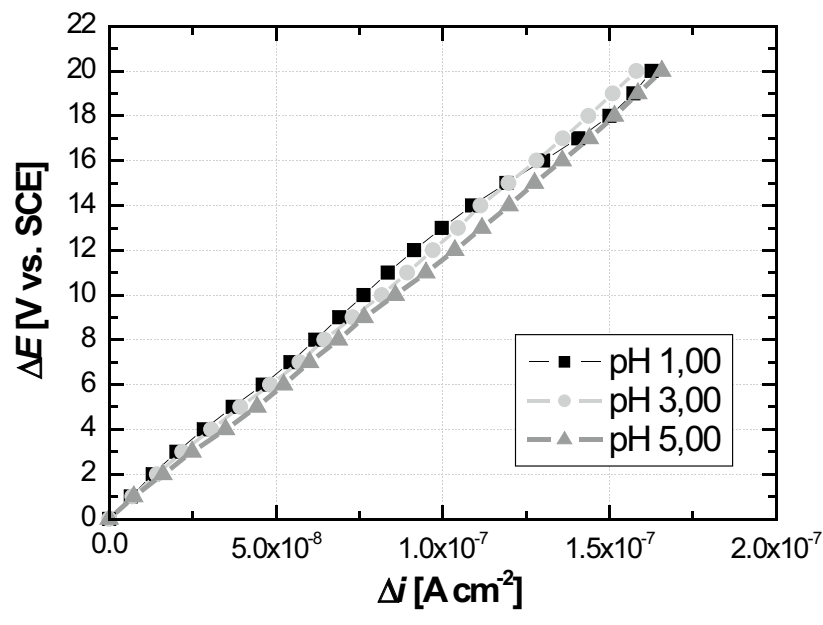

B)

Fig. 9 A Potentiokinetic curves recorded in a solution with a variable $\mathrm{pH}$ saturated with hydrogen. B Change in the value of external current as a function of the applied voltage (in the range of $E_{\text {corr }}+\Delta E$ ) of the analyzed material on the basis of the recorded potentiokinetic curves

potentiokinetic curves, carbon materials are not covered with oxide layers or other layers created in a given environment, inhibiting corrosion processes in the cell's working environment. The carbon passivation phenomenon would be possible if the oxidation products of the metal elements of the fuel cell parts were deposited on the carbon surface.

The polarization resistance $R_{\mathrm{p}}$ was determined on the basis of the recorded potentiokinetic curves presented in Fig. 8A and Fig. 9A. The dependence was used that in the range of $E_{\text {corr }} \pm 20 \mathrm{mV}$, the external current density is a linear function of the potential, and the tangent of the slope of the $E=f(i)$ relationship is inversely proportional to the corrosion rate. As can be seen from the data presented in Fig. 8B, the lowest slope was estimated at $\mathrm{pH} 3.00$, which means that the sintered graphite shows the lowest corrosion resistance, including $\mathrm{pH}$ in a saturated oxygen solution (near-cathode conditions). Under conditions simulating anode conditions, regardless of the changing $\mathrm{pH}$ of the solution, sintered graphite will show high resistance to $R_{\mathrm{p}}$

Table 4 Corrosion parameters estimated on the basis of the potentiokinetic curves obtained in cathode conditions $\left(\mathrm{O}_{2}\right.$ saturated solution), based on Fig. 8

\begin{tabular}{lllll}
\hline & $\begin{array}{l}E_{\text {corr }} \\
{[\mathrm{V} \text { vs. SCE] }}\end{array}$ & $\begin{array}{l}i_{\text {corr }} \\
{\left[\mathrm{A} \mathrm{cm}^{-2}\right]}\end{array}$ & $\begin{array}{l}R_{\mathrm{p}} \\
{\left[\mathrm{k} \Omega \mathrm{cm}^{2}\right]}\end{array}$ & $\begin{array}{l}i \text { at } 0.6 \mathrm{~V} \text { vs. SCE } \\
{\left[\mathrm{A} \mathrm{cm}{ }^{-2}\right]}\end{array}$ \\
\hline pH 1 & 0.112 & $3.44 \cdot 10^{-6}$ & 451 & $\begin{array}{l}3.21 \cdot 10^{-6} \\
\end{array}$ \\
& $\sigma=0.0015$ & $\sigma=6.3 \cdot 10^{-7}$ & $\sigma=10$ & $\sigma=2.3 \cdot 10^{-7}$ \\
pH 3 & 0.017 & $1.88 \cdot 10^{-6}$ & 209 & $7.78 \cdot 10^{-6}$ \\
& $\sigma=0.0015$ & $\sigma=5.5 \cdot 10^{-7}$ & $\sigma=6.5$ & $\sigma=1.9 \cdot 10^{-7}$ \\
pH 5 & -0.020 & $1.51 \cdot 10^{-6}$ & 765 & $4.36 \cdot 10^{-6}$ \\
& $\sigma=0.0076$ & $\sigma=4.0 \cdot 10^{-7}$ & $\sigma=13$ & $\sigma=6.2 \cdot 10^{-7}$ \\
\hline
\end{tabular}

polarization (Fig. 9B) and a comparable slope of the $E=f$ (i) curve developed for each of the potentiokinetic curves in Fig. 9A.

The oxide layer generated in the passive range of the material constitutes an insulating barrier, causing a decrease in electrical conductivity in the cell. Shores and Deluga [31] indicate that in the initial phase of the $\mathrm{H}_{2}$ /air (PEMFC) cell operation, the environment is acidic $(\mathrm{pH}=1.00-4.00)$, while after some time of cell operation, the environment changes to $\mathrm{pH}=6.00-7.00$ [32]. Taking into account the phenomena occurring in the fuel cell, in order to test the corrosion resistance of materials, a solution of $0.1 \mathrm{~mol} \mathrm{dm}^{-3}$ $\mathrm{Na}_{2} \mathrm{SO}_{4}+2 \mathrm{ppm} \mathrm{F}^{-}$with $\mathrm{pH} 1.00, \mathrm{pH} 3.00$, and $\mathrm{pH} 5.00$ was proposed [21, 33-35].

Table 4 presents the values of the corrosion parameters estimated on the basis of the potentiokinetic curves presented in Fig. 8 A, B. Both in cathode and anode conditions, at low and high $\mathrm{pH}$ of the solution, the corrosion potential ranges from -0.020 to $0.200 \mathrm{~V}$ vs. SCE. The value of the

Table 5 Corrosion parameters estimated on the basis of the potentiokinetic curves obtained in cathode conditions $\left(\mathrm{H}_{2}\right.$ saturated solution), based on Fig. 8

\begin{tabular}{lllcl}
\hline & $\begin{array}{l}E_{\text {corr }} \\
{[\mathrm{V} \text { vs. SCE }]}\end{array}$ & $\begin{array}{l}i_{\text {corr }} \\
{\left[\mathrm{A} \mathrm{cm}{ }^{-2}\right]}\end{array}$ & $\begin{array}{l}R_{\mathrm{p}} \\
{\left[\mathrm{k} \Omega \mathrm{cm}^{2}\right]}\end{array}$ & $\begin{array}{l}i \text { at }-0.1 \mathrm{~V} \text { vs. SCE } \\
{\left[\mathrm{A} \mathrm{cm}{ }^{-2}\right]}\end{array}$ \\
\hline pH 1 & 0.192 & $7.34 \cdot 10^{-6}$ & 430 & $1.06 \cdot 10^{-6}$ \\
& $\sigma=0.0042$ & $\sigma=5.5 \cdot 10^{-7}$ & $\sigma=3.6$ & $\sigma=7.7 \cdot 10^{-7}$ \\
pH 3 & 0.057 & $6.18 \cdot 10^{-6}$ & 633 & $1.52 \cdot 10^{-6}$ \\
& $\sigma=0.0045$ & $\sigma=1.6 \cdot 10^{-7}$ & $\sigma=11$ & $\sigma=8.1 \cdot 10^{-7}$ \\
pH 5 & 0.025 & $8.15 \cdot 10^{-6}$ & 733 & $1.14 \cdot 10^{-6}$ \\
& $\sigma=0.006$ & $\sigma=1.3 \cdot 10^{-7}$ & $\sigma=9.5$ & $\sigma=4.6 \cdot 10^{-7}$ \\
\hline
\end{tabular}


Fig. 10 Potentiostatic curves obtained in cathode $(E=0.6 \mathrm{~V}$ vs. SCE, solution saturated with oxygen) and anode $(E=-0.1 \mathrm{~V}$ vs. SCE, solution saturated with hydrogen) conditions

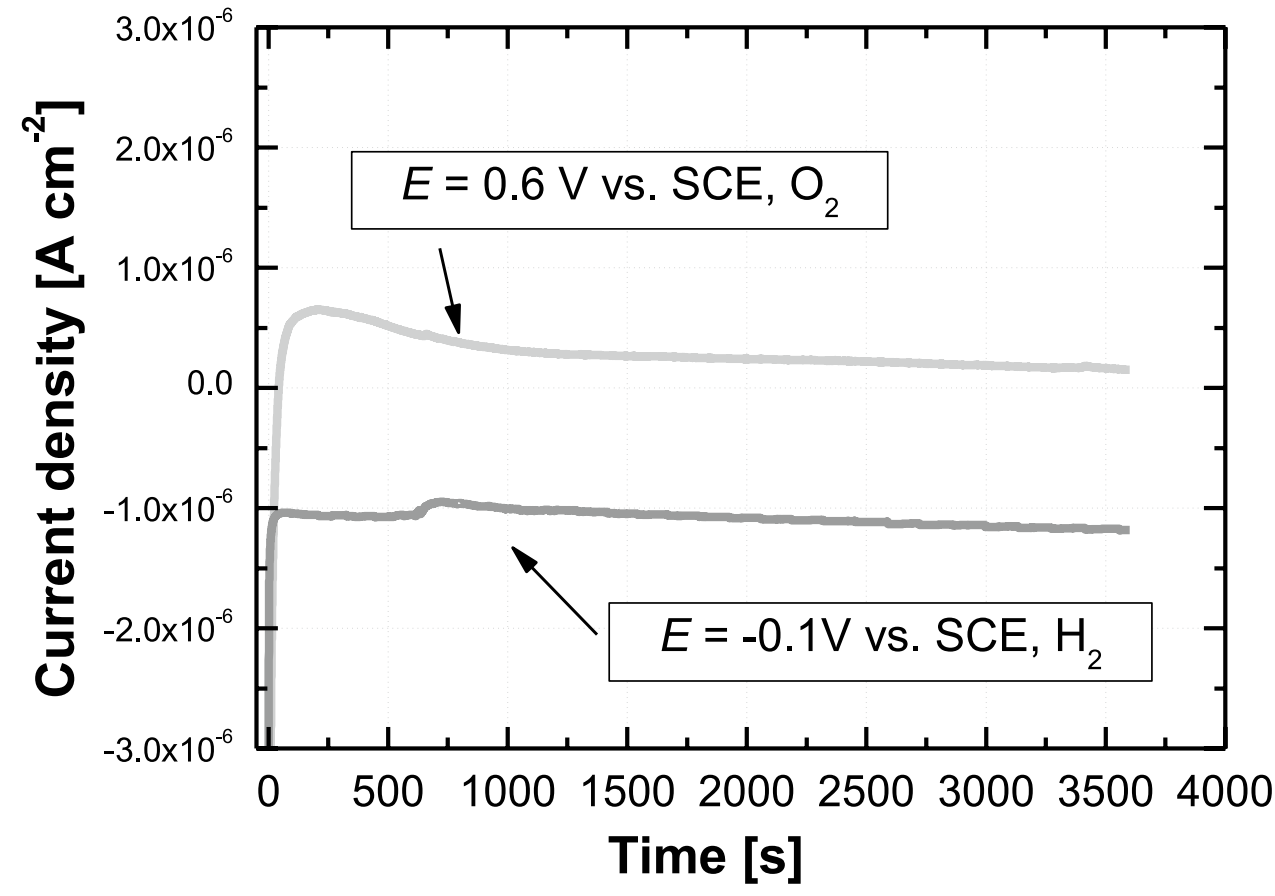

corrosion current oscillates below the limit of the requirements formulated by the DOE $\left(<16 \cdot 10^{-6} \mathrm{~A} \mathrm{~cm}^{-2}\right)$. High polarization resistance values additionally prove the high resistance of the material in the tested conditions. Corrosion rates determined by extrapolation of Tafel sections indicate high corrosion resistance of graphite materials under dynamic conditions. Potentiostatic tests were carried out in a solution of $0.1 \mathrm{~mol} \mathrm{dm}{ }^{-3} \mathrm{H}_{2} \mathrm{SO}_{4}+2 \mathrm{ppm} \mathrm{F}^{-}$, $T=80{ }^{\circ} \mathrm{C} \pm 2{ }^{\circ} \mathrm{C}$, saturated with hydrogen or oxygen, produced from the electrolyser (Table 5). Figure 9 presents the recorded potentiokinetic curves recorded for graphite sintered in a corrosive solution saturated with hydrogen.

Figure 10 presents the course of changes in the value of the current density in time under the conditions of constant potential corresponding to the processes taking place in the hydrogen cell under the anodic conditions $(E=-0.1 \mathrm{~V}$ vs. SCE) and in the near-cathode conditions ( $E=0.6 \mathrm{~V}$ vs. $\mathrm{SCE}$ ). The chronoamperometric method of corrosion resistance analysis shows that the lower the current density value at a given potential, the better the material's resistance. Both chronoamperometric curves recorded at potentials of $0.6 \mathrm{~V}$ and $-0.1 \mathrm{~V}$ vs. SCE started their course at current density values of approx. $-3.0 \cdot 10^{-6} \mathrm{~A} \mathrm{~cm}^{-2}$. In the case of analysis under anodic conditions, the curve reached a plateau after $90 \mathrm{~s}$ after the start of the measurement, in the case of analysis under cathode conditions, the current density stabilized after approx. $800 \mathrm{~s}$. The current values determined in the static cathode and anode conditions of the fuel cell are respectively $2.35 \cdot 10^{-7} \mathrm{~A} \mathrm{~cm}^{2}\left(\mathrm{O}_{2}\right)$ and $-1.14 \cdot 10^{-6} \mathrm{~A} \mathrm{~cm}^{-2}\left(\mathrm{H}_{2}\right)$. These values are comparable to the corrosion current density values determined on the basis of potentiodynamic tests. A positive sign at the current density values indicates the absence of corrosion processes; a negative value indicates the material dissolution processes taking place under given conditions [36].

\section{Conclusions}

Fuel cells are generators that produce electricity by oxidizing hydrogen and reducing oxygen. The use of this type of generators gives an opportunity to reduce pollutant emissions and increase the share of renewable fuels in the global perspective. The structure and function of hydrogen fuel cells are well known and well defined. In serial production of fuel cells, an important aspect is the selection of materials for individual elements of the cell. Properly selected material ensures correct operation of the cell, high efficiency, and the required lifetime of the elements. As part of the work, the material for the construction of bipolar plates for low-temperature fuel cells was manufactured, designed, and tested.

The analysis of the properties of sintered graphite allows for the following statements:

- Powder metallurgy technology allows to obtain a product with the desired properties by selecting process parameters, such as powder sizes, pressing pressure, and sintering temperature;

- Low density of the obtained sinter used as a cell cover allows to reduce the mass of the cell; 
- The produced material belongs to the group of hydrophobic materials;

- Analysis of porosity shows pores in the meso- and macropore range in the tested material;

- The roughness profile examined for the tested sintered graphite indicates the obtaining of relatively smooth materials, where $R_{\mathrm{a}}$ is distributed in the range between +5.0 and $-7.5 \mu \mathrm{m}$ from the mean line profile;

- Carbon materials are not covered with oxide layers or other layers created in a given environment, inhibiting corrosion processes in the cell's working environment: anode (hydrogen-saturated solution) and cathode (oxygen-saturated solution) conditions;

- Along with the increase in $\mathrm{pH}$ during the cell operation, the corrosion resistance of the graphite sinter determined on the basis of pentiokinetic measurements, expressed in $R_{\mathrm{p}}$, increases;

- Graphite sinters show high resistivity in both tested corrosive environments, which allows the use of powder metallurgy technology for serial production of covers for low-temperature fuel cells.

Funding The scientific research was funded by the statute subvention of Czestochowa University of Technology, Faculty of Infrastructure and Environment. The research was funded by the project No. BS/ PB400/301/21.

Open Access This article is licensed under a Creative Commons Attribution 4.0 International License, which permits use, sharing, adaptation, distribution and reproduction in any medium or format, as long as you give appropriate credit to the original author(s) and the source, provide a link to the Creative Commons licence, and indicate if changes were made. The images or other third party material in this article are included in the article's Creative Commons licence, unless indicated otherwise in a credit line to the material. If material is not included in the article's Creative Commons licence and your intended use is not permitted by statutory regulation or exceeds the permitted use, you will need to obtain permission directly from the copyright holder. To view a copy of this licence, visit http://creativecommons.org/licenses/by/4.0/.

\section{References}

1. Felseghi RA, Carcadea E, Raboaca MS, Trufin CN, Filote C (2019) Energies 12:4593. https://doi.org/10.3390/en12234593

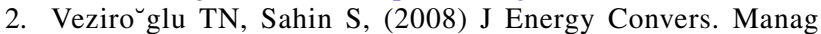
49:1820-1831

3. Dincer I (2012) Int J Hydrogen Energy 37:1954-1971

4. Jayakumar K, Pandiyan S, Rajalakshmi N, Dhathathreyan KS (2206) J Power Sources 161:454-459

5. Hermann A, Chaudhuri T, Spagnol P (2005) Int J Hydrogen Energy 30:1297-1302

6. Mehta C, Cooper JS (2003) J Power Sources 114:32-53
7. Lee S-J, Huang C-H, Lai J-J, Chen Y-P (2004) J Power Sources 131:162-168

8. Antepara I, Villarreal I, Rodríguez-Martínez LM, Lecada N, Castro U, Leresgoiti A (2005) J Power Sources 151:103-107

9. Lee S-J, Lai J-J, Huang C-H (2005) J Power Sources 145:362-368

10. Wlodarczyk R (2011) Research on the functional properties of materials used for PEMFC fuel cell interconnectors. Publisher Czestochowa University of Technology, Czestochowa

11. Amin MA, Ibrahim MM (2011) Corros Sci 53:873-885

12. Elleuch A, Boussetta A, Yu J, Halouani K, Li Y (2013) Int J Hydrogen Energy 38:8519-8523

13. Barber M, Sun TS, Petrach E, Wang X, Zou Q (2008) J Power Sources 185:1252-1256

14. Cunningham BD, Baird DG (2007) J Power Sources 168:421-425

15. Posmyk A, Chmielnik IP (2010) Composites 10:229-234

16. Cybo J, Gołąb A, Służałek G (2000) Solidification of Metals and Alloys 2:433-438

17. Cheung P, Fairweather JD, Schwarz DT (2009) J Power Sources 187:487-492

18. Ciao K, Zhou B (2008) J Power Sources 175:106-119

19. Kannan AM, Cindrella A, Munukutla L (2008) Electrochim Acta 53:2416-2422

20. Jiao K, Zhou B (2008) J Power Sources 175:106-119

21. Wlodarczyk R (2018) J Ecological Eng 19:202-213

22. Borup R (2007) Chem Rev 107:3904-3951

23. Wlodarczyk R, Kolary-Żurowska A, Marassi R, Chojak M, Kulesza PJ (2007) Electrochim Acta 52:3958-3964

24. Wlodarczyk R, Chojak M, Miecznikowski K, Kolary A, Kulesza PJ, Marassi R (2006) J Power Sources 159:802-809

25. Mathias MF, Makharia R, Gasteiger HA, Conley JJ, Fuller TJ, Gittleman CJ, Kocha SS, Miller DP, Mittelsteadt CK, Xie T, Yan SG, Yu PT (2005) Electrochem Soc Interface 14:24-35

26. Roen LM, Paik CH, Jarvi TD (2004) Electrochem Solid-State Lett 7:A19

27. Chojak M, Mascetti M, Wlodarczyk R, Marassi R, Karnicka K, Miecznikowski K, Kulesza PJ (2004) J Solid State Electrochem 8:854-860

28. Wlodarczyk R, Wrońska A (2013) Arch Metall Mater 58(1):89-93

29. Schultz T, Krewer U, Sundmacher K (2007) J Power Sources 165:148-151

30. Rho YW, Srinivasan S, Kho YT (1994) J Electrochem Soc 141(8):2084-2089

31. Shores DA, Deluga GA (2003) Handbook of fuel cells - fundamentals, technology and applications. New York, Wiley, p 273

32. Lee Y-B, Lee C-H, Lim D-S (2009) Int J Hydrogen Energy 34:9781-9787

33. Borup RL, Vanderburgh NE (1995) Proces Mat, Res., Soc. Symp 393:151-155

34. Fleury E, Jayaraj J, Kim YC, Seok HK, Kim KY, Kim KB (2006) J Power Sources 159:34-37

35. Wlodarczyk R (2018) Functional Mat Lett 1930001. https://doi. org/10.1142/S1793604719300019

36. Kai F, Guosong W, Zhuguo L, Xun C, Chu PK (2011) Int J Hydrogen Energy 36:13032-13042

37. IUPAC- International Union of Pure and Applied Chemistry. www.iupac.org

Publisher's Note Springer Nature remains neutral with regard to jurisdictional claims in published maps and institutional affiliations. 